\title{
British Nutrition Foundation
}

THE British Nutrition Foundation was first incorporated in February 1967, and although the organization has had a busy and even a successful year, the foundation's name is still in large measure a synonym for Professor Alastair Frazer, for several years a prominent figure among nutritionists. His academic work at Birmingham, where he was professor of medical biochemistry until a year ago, was a sufficient assurance of that. But Dr Frazer has also been closely associated with other organizations concerned with the public use and public safety of foods and drugs of various kinds. For some years, for example, he has been chairman of the British Food Manufacturing Industries Research Association. He has been closely associated with the committees supported by the Nuffield Foundation which have been devoting attention to various aspects of food safety-additives, for example - in the past few years. He is also a member of the Dunlop Committee, which is now the centrepiece of the somewhat informal machinery by means of which drugs are introduced on to the British pharmaceutical market. Inevitably, Dr Frazer's influence is bound to be a great help to the foundation in the years immediately ahead.

Dr Frazer says that his objective at the foundation is to create machinery for coordinating research and education in nutrition. Of the need for some such device, there can be no doubt. Dr Frazer himself points out that research and responsibility for research is at present widely dispersed through the Government, industry and the universities. The Ministry of Health, for example, is responsible for human nutrition, but the Ministry of Agriculture, Fisheries and Food for animal health and breeding. Dr Frazer also regrets the gulf which at present divides nutritionists from food scientists. "They live in separate worlds," he says. And in the half a dozen or so departments of food science and technology in the universities, nutrition is scarcely recognized as a subject in its own right. Such teaching as there is tends to be found in depart. ments of biochemistry and physiology.

How will the new foundation cure all this? Dr Frazer's concept of his foundation's function is that of a catalyst. He talks of bringing people together for committee meetings at which problems of nutrition policy will be thrashed out and sometimes resolved. One of the results he hopes for is a better definition of some of the problems to be solved, and a clearer view of what kinds of research are needed. On a technical level, he plans to set up interdisciplinary groups to tackle specific problems in food science and nutrition. Eventually there may be rather more elaborate meetings-Dr Frazer mentioned the Ciba symposia as a possible model for one way of working. He argues that the foundation could also become a forum in which scientists and nutritionists could meet officials from government departments, to the benefit of both sides and with a practical result that public issues such as the use of cyclamates as artificial sweeteners might be less highly charged.

Dr Frazer also has in mind a less technically oriented programme of education. For one thing, there is an information bulletin intended to disseminate information to manufacturers, members of parliament, university teachers and any who ask for it. The first issue of the Information Bulletin, published some weeks ago, took several bulls by the horns, with lucid comments on three current public issues-the use of cyclamates in food, the possibly carcinogenic effects associated with the use of nitrates as preservatives and the relationship between sugar and heart disease (which Dr Frazer discounts). Farther away, there is a possibility of exploiting radio and television, and even the possibility of graduate courses on the university of the air.

In time there may also be a programme of grantgiving for university departments concerned with nutrition. Dr Frazer would particularly like to encourage new people to enter the field, and hopes that quite small grants could bring great benefits in that respect. As a start, he has circulated the heads of some 250 university departments who may have some interest in nutrition, but the few small grants so far awarded are small in aggregate as well in these early days.

But who will pay for all this? For the next seven years - the lifetime of a tax-deductible covenant-the foundation will live on a budget of at least $\mathfrak{E 6 5 , 0 0 0}$ a year-the amount already subscribed by several food manufacturers. The foundation's guarantors include several household names-Allied Farm Foods, Beechams, Heinz, Marks and Spencer, Rank Hovis, Schweppes, Spillers, Tate and Lyle and Unilever. Other subscribers include the Coca Cola Export Corporation and the Distillers Company, Procter and Gamble and the Milk Marketing Board. The chairman of the council which runs the foundation is Sir Charles Dodds, and it consists of a board representative of both the industry and science. The council is advised by a scientific advisory committee of academic scientists and also by a separate committee of industrial scientists.

The predominance of food manufacturers has perhaps inevitably raised the question whether $\mathrm{Dr}$ Frazer's foundation is not so much an educational foundation as a lobby for the food industry. Dr Frazer himself is entirely forthright on this subject. For one thing, with justice, he points to the distinguished membership of the committees which provide scientific advice. For another, he argues that the interests of the food industry are necessarily so diverse that what is good for one company will be poison for another. But may there not be circumstances in which the food industry as a whole has common cause ? And what would the foundation do then? As with all institutions, the foundation's reputation will depend on its record. There should be no shortage of opportunities, in the months ahead, for it to demonstrate where it stands.

(On cyclamates, Dr Frazer takes the view that there is no evidence at present to suggest that cyclamates are harmful or to provide a guarantee that they are safe, which implies that continued use is prudent but that more research is necessary.) 